\title{
室内における調湿建材による調理臭の 脱臭性能に関する検討
}

\author{
棚村 壽三，光田＼cjkstart恵，佐々木 寛篤，小林 和幸
}

\begin{abstract}
本研究では，IH 調理時に，換気量削減のためレンジフードによる局所排気をしない場合の臭気対策とし て調湿建材に着目し，実物大空間における調湿建材の脱臭性能を明らかにすることを目的とした。 LDKを 想定した実験室 $(3640 \mathrm{~mm} \times 7280 \mathrm{~mm} \times 2500 \mathrm{~mm}$ ，換気回数 0.5 回 $/ \mathrm{h} ）$ で IH による調理を行い，調湿建材 （主成分：多孔質珪酸化合物）を設置したときの脱臭性能を嗅覚測定とにおいセンサーを用いて評価した。 調理直後の臭気濃度を基に, 実験室の壁・天井をガラスとしレンジフードを全く運転しない条件に対する各 条件の低減率を脱臭率として求め, 脱臭性能を比較した。実験室の天井に調湿建材を設置した条件では脱臭 率 $69 \%$ であり, 調理中 15 分間のみのレンジフード運転条件では脱臭率 $90 \%$ であった. 調湿建材の調理直後 の脱臭率は 15 分間運転のレンジフードよりも劣るが，調湿建材は室内へ残留した臭気の脱臭に有効であり， 調理前の臭気濃度までに回復する時間は，調理中 15 分間のレンジフード運転条件よりも短くなることが明 らかとなった。
\end{abstract}

\section{1. 緒言}

現在，一般家庭の調理時に使用される熱源にはガスレ ンジと電磁誘導加熱器具（以下，IH）がある。 ガスで調 理を行う際には，燃焼によって $\mathrm{CO}_{2}$ 等の污染物質が発生 するため換気する必要がある. IH の場合には電磁誘導 による加熱であり，ガスのように $\mathrm{CO}_{2}$ が発生しないた め, 換気量を削減できる可能性があるが, 換気量削減に よる臭気，油煙，水蒸気などの影響が懸念される ${ }^{1)}$ 。 た，近年の住宅に拈いて，LDK の間取りが多い現状を考 えると, 調理時に発生した臭気が LDK の広範囲に拡 がっており，その対策が必要である。

一方，調湿建材は，室内湿度の調節機能を持つ建材で ある ${ }^{2)}$ が，吸着による脱臭作用も注目されている ${ }^{3)}$. 調湿 建材の脱臭性能に関連する研究としては, 化学物質の吸 着性能を検討しているものが多く，例えば，鈴木ら ${ }^{4)}$ の ホルムアルデヒドの吸着性能に関する小型チャンバー実 験, 桑沢 ${ }^{5)}$ の化学物質の吸着性能に関する実物大の空 間での実験などがある。また，横田らの研究6) のように， 実大スケールの住宅における建材の設置位置が室内化学 物質濃度低減性能に及ぼす影響を数值流体解析手法によ り検討したものもみられる．脱臭性能を検討した例とし ては，小峯ら ${ }^{7)}$ の焼肉臭のフレーバーを用いて $10 \mathrm{~cm} \times$
$10 \mathrm{~cm}$ の建材の脱臭性能をにおい識別装置により測定し た研究, 吉田ら ${ }^{8)}$ の調湿建材の脱臭性能を小型チャン バーにより検討した研究がみられるが，実物大の空間を 用いた調湿建材の脱臭性能試験は行われていない.

本研究では, IH 調理時に, 換気量削減のためレンジ フードによる局所排気をしない場合の臭気対策として調 湿建材に着目し，実物大空間における調湿建材の脱臭性 能を明らかにすることを目的とした。 また，調理時には 水蒸気も発生することから室内の温湿度を測定し，参考 として調湿性能も検討した。

\section{2. 方法}

\section{1 実験材料}

本実験に用いた調湿建材は厚さ $6 \mathrm{~mm}$ であり，主に調 湿機能を有する芯層部分は多孔質珪酸化合物からなり, 建材の表裏は透湿性を持つ塗装が施されている。主とし て下地材として使用される建材である。

\section{2 実験方法および実験装置}

先に述べたとおり調湿建材のホルムアルデヒドおよび VOC の吸着性能に関する検討はみられるが，調理臭の 脱臭効果を評価した例は少ない。そこで，まず調理時に 発生する臭気成分を分析し, 最も多く検出された臭気成

\footnotetext{
棚村 壽三 (たなむら としみ)*, 光田 恵（みつだ めぐみ）**, 佐々木 寛篤（ささき ひろあつ）***, 小林 和幸（こばや し かずゆき)****

$*$ 大同大学大学院工学研究科

**大同大学情報学部情報デザイン学科かおりデザイン専攻

***元大同大学大学院工学研究科

****東京電力株式会社
} 
分に対する調湿建材の基本性能（吸着性能，保持性能） を把握するための予備試験を実施した。次に本試験とし て, 調湿建材の調理臭成分の吸着性能を確認した上で, 0.5 回/h の換気が行われている実験室に調湿建材を設置 し，複合臭である調理臭の脱臭性能を評価した。本試験 では，IH 調理時にレンジフードを使用しない場合の臭 気対策として調湿建材の脱臭性能を明らかにすることが 目的であるため, 次の 4 条件で調湿建材による調理臭の 脱臭性能を比較した。 その 4 条件は, 実験室の壁面・天 井面ともガラスでレンジフードを運転しない条件，実験 室の壁面・天井面ともガラスで調理中 15 分間のみレン ジフードを運転する条件, 実験室の壁面に調湿建材を設 置しレンジフードを運転しない条件, 実験室の天井に調 湿建材を設置しレンジフードを運転しない条件である.

\section{2.1 調湿建材の調理臭成分に対する吸着性能試験 （予備実験）}

調理時に発生する臭気成分分析については，ガスクロ マトグラフにより行った ${ }^{9)}$. 臭気試料の採取を行った実 験室の平面図と調理場所および試料採取点は図ー1 に示 すとおりである。実験室は 15 畳相当の LDK 一体型を想 定した空間であり，臭気の吸着を少なくするため，床は アクリル板，壁・天井はガラス仕上げとなっている。リ ビング側に設置した換気扇による室内の換気量を約 0.5 回/h に設定し，熱源真上に設置したレンジフード（深型 レンジフード) の排気風量を $300 \mathrm{~m}^{3} / \mathrm{h}$ に設定した。 レン ジフードの捕集効率（BLT VU-07 の方法にて測定）は $86.9 \%$ であった。実験中，扉は全て閉じ，試料採取のた めに出入りする屝には, 実験室内の臭気が外に漏れるこ とを軽減させるためにカーテンを取り付けた.

調理品として, 焼肉 (牛肉 $400 \mathrm{~g}$, 焼肉のたれ $120 \mathrm{cc}$, 油 $60 \mathrm{~g}$ ) を選定した. 直径 $28 \mathrm{~cm}$, 深さ $7.5 \mathrm{~cm}$, 底板の厚さ $3 \mathrm{~mm}$ のフ
ライパン（(株)ベストコ）を用い，調理時間を 15 分間と した。 あらかじめ牛肉 $400 \mathrm{~g}$ と焼肉のたれ $120 \mathrm{cc}$ を混ぜ ておき，点火し，フライパンを 45 秒間温め，油 $15 \mathrm{cc}$ を 入れ 15 秒加熱した後, たれ付きの肉 $100 \mathrm{~g}$ を入れ 3 分 間調理する作業を 4 回繰り返した。 IH クッキングヒー

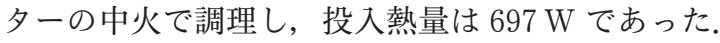

臭気成分分析のために用いた試料は，レンジフードを 運転しない条件で調理を行い，調理直後に図-1の試料 採取点で採取したものである。試料採取用袋（近江オド

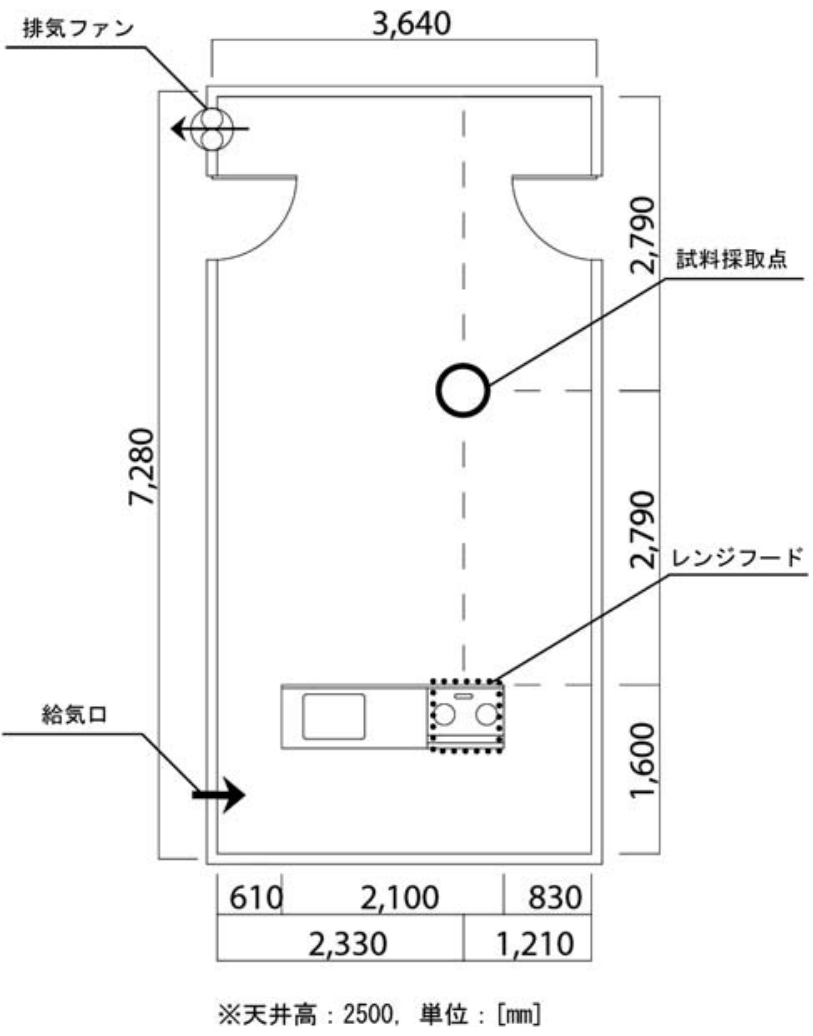

図-1 実験室の平面図

表 -1 臭気成分の分析条件

\begin{tabular}{|c|c|c|c|c|c|}
\hline & アルデヒド類 & 含硫黄化合物 & $\begin{array}{c}\text { 脂肪酸類・ } \\
\text { 脂肪族アルコー類 }\end{array}$ & 芳香族炭化水素類 & トリメチルアミン \\
\hline カラム & 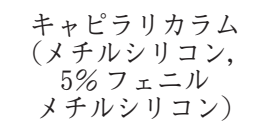 & $\begin{array}{c}25 \% \beta, \beta^{\prime}-\text { オシジプ } \\
\text { ロピオニトリル }\end{array}$ & $\mathrm{FFAP}+\mathrm{H} 3 \mathrm{PO} 4 / 0.3+0.3 \%$ & $\begin{array}{rl}5 \% & \mathrm{SP} 1200 \\
+ & 1.75 \% \text { ベントン } 34\end{array}$ & $\begin{array}{l}15 \% \text { ジグリセロール } \\
+5 \% \text { TEP }+2 \% \mathrm{KOH}\end{array}$ \\
\hline カラム温度 & $\begin{array}{l}100^{\circ} \mathrm{C}(1 \text { 分保持 }) \sim \\
200^{\circ} \mathrm{C}\left(10^{\circ} \mathrm{C} / \mathrm{min}\right)\end{array}$ & $70^{\circ} \mathrm{C}$ & $80^{\circ} \mathrm{C}$ & $80^{\circ} \mathrm{C}$ & $50^{\circ} \mathrm{C}$ \\
\hline 検出温度 & $300^{\circ} \mathrm{C}$ & $150^{\circ} \mathrm{C}$ & $250^{\circ} \mathrm{C}$ & $180^{\circ} \mathrm{C}$ & $150^{\circ} \mathrm{C}$ \\
\hline 試料導入部温度 & - & $130^{\circ} \mathrm{C}$ & $250^{\circ} \mathrm{C}$ & $180^{\circ} \mathrm{C}$ & $130^{\circ} \mathrm{C}$ \\
\hline 試料入口温度 & $250^{\circ} \mathrm{C}$ & $150^{\circ} \mathrm{C}$ & - & - & - \\
\hline キャリアーガス & He（超高純度） & $\mathrm{N}_{2}$ （超高純度） & $\mathrm{N}_{2}$ （超高純度） & $\mathrm{N}_{2}$ （超高純度） & $\mathrm{N}_{2}$ （超高純度） \\
\hline ガス流量 & $30 \mathrm{~mL} / \mathrm{min}$ & $40 \mathrm{~mL} / \mathrm{min}$ & $40 \mathrm{~mL} / \mathrm{min}$ & $40 \mathrm{~mL} / \mathrm{min}$ & $50 \mathrm{~mL} / \mathrm{min}$ \\
\hline 検出器 & FTD & FPD & FID & FID & FID \\
\hline 装置 & GC-14B（島津製作所） & GC-14B（島津製作所） & GC-2014（島津製作所） & GC-2014（島津製作所） & GC-14B（島津製作所） \\
\hline
\end{tabular}


エアーサービス，フレックサンプラー F タイプ) と 15〜 $20 \mathrm{~L} / \mathrm{min}$ のポンプ（近江オドェアーサービス, フレック スポンプ DC1-NA 型) を使用して試料を $150 \mathrm{~L}$ 採取し, 分析室で，脂肪酸類測定用試料はガラスビーズに固体捕 集を行い，芳香族炭化水素類測定用試料はテナックス TA に固体捕集を行った。 各臭気成分の分析条件を表一1に 示す。アンモニアに関しては分光光度計を用いて分析を 行った。試料ガスをほう酸溶液で捕集し，捕集溶液に フェノール・ペンタシアノニトロシル鉄（III）酸ナトリ ウム溶液および次亜塩素酸ナトリウム溶液を加え, アン モニウムイオンと反応して生成するインドフェノール青 の吸光度を测定してアンモニアを定量した。

調湿建材の調理臭成分に対する吸着性能試験について は, 厚さ $6 \mathrm{~mm}$ の調湿建材を $6 \mathrm{~mm}$ 角に加工し, 試験片 として用いた。その試験片 9 個をカラム（直径 $10 \mathrm{~mm}$, 長さ $80 \mathrm{~mm}$ ）に詰めて試験体カラムとした。試験体カラム の吸着物質の影響を抑えるために，実験開始前に $80^{\circ} \mathrm{C}$ に設 定した恒温器内に試験体力ラムを入れ, 窒素を $10 \mathrm{~mL} / \mathrm{min}$ で 10 日間流した。図－2に調湿建材の調理臭成分に対す る吸脱着性能を確認する実験装置を示す。後述する調理 臭の成分分析の結果を基に，予備実験には調理臭成分と してアンモニアを用いた。試験体カラム内へは $2 \mathrm{~L} / \mathrm{min}$ でアンモニア（アンモニア設定濃度を 6 段階臭気強度で 2.5 相当の $1.5 \mathrm{ppm}^{9)}$ とした.）を流した。インキュベー ター内は $25^{\circ} \mathrm{C}$ に設定し，3 時間ごとにカラムの出入口ガ ス濃度を検知管（北川式ガス検知管 $105 \mathrm{SD}$, アンモニア 検出下限濃度 $0.1 \mathrm{ppm}$ ）で測定した。 カラムの出入口濃 度が一致した点を飽和点と判断した。

飽和状態に達した場合，調理臭成分が調湿建材から放出 する可能性が考えられるため, 調湿建材の脱臭性能を検討 する参考資料として, 再放出実験を行った. 再放出実験で はインキュベーター内の温度を夏季室内の高温時を想定し て $40^{\circ} \mathrm{C}$ まで上昇させ，吸着実験之同様の流量 $2 \mathrm{~L} / \mathrm{min} の$ 窒素を流した。再放出実験では 30 分間隔でカラム出口
のガス濃度を検知管で測定し，検出下限值以下になった 時を実験終了とした。

\section{2. 2 調湿建材の調理臭に対する脱臭性能試験}

調湿建材の施工した場所は，図－3に示す天井面また は壁面であり，施工面積については，メーカーが提示し ている 16 䡒に対して湿度調整に適切とされる $22.8 \mathrm{~m}^{2}$ を 考慮し，設置面積を決定した。

実験条件は，レンジフード停止・調湿建材なし（以下， レンジフードなし)，レンジフード停止・調湿建材の設 置場所が天井 (以下, 調湿 (天井)), レンジフード停止・ 調湿建材の設置場所が壁 (以下, 調湿 (壁)), レンジフー

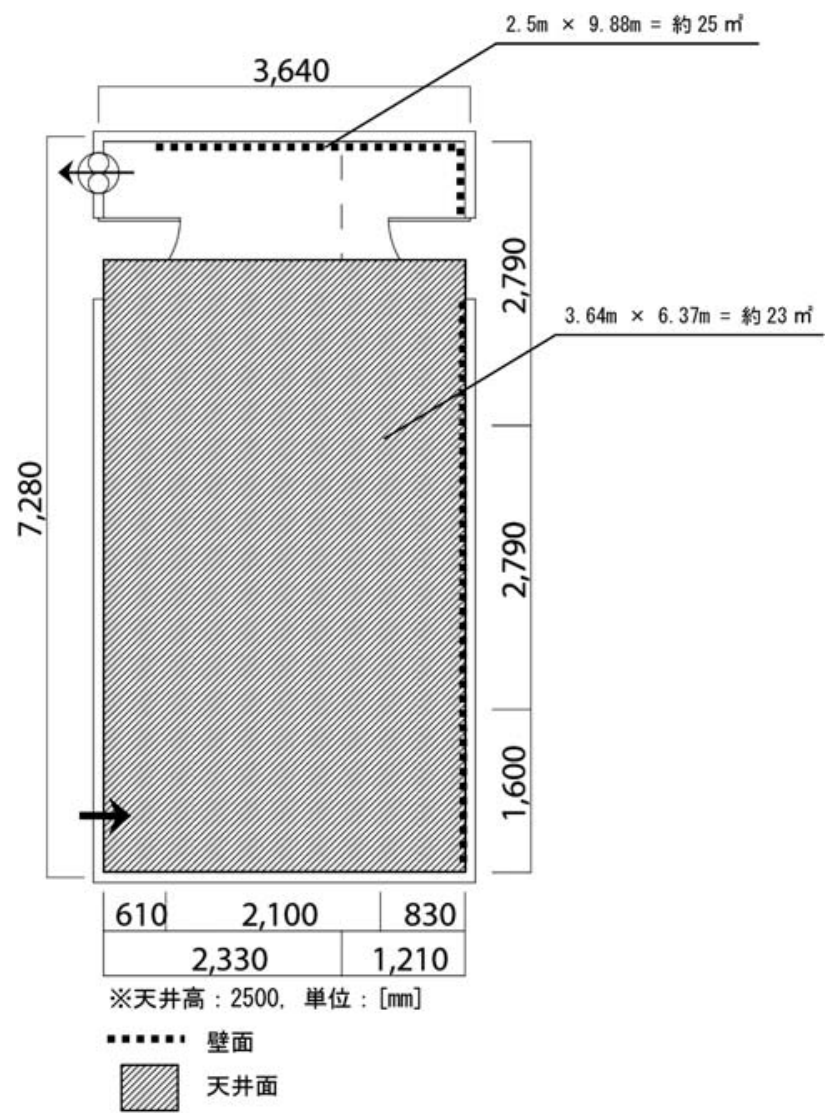

図－3＼cjkstart実験室における調湿建材の施工場所

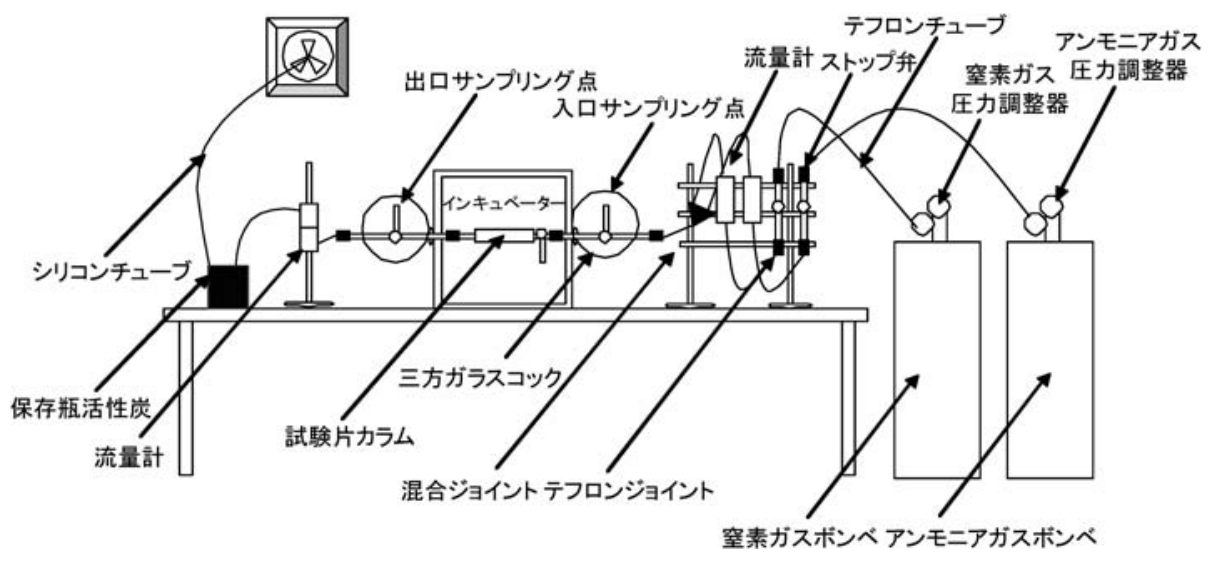

図－2 調湿建材の調理臭成分に対する吸脱着性能を確認する装置 
ドを調理中の 15 分間のみ運転・調湿建材なし（以下，レ ンジフードあり）の 4 条件とした。

機器測定については, 図一 1 に示す試料採取点（○の 位置) の床上 $50 \mathrm{~cm}, 150 \mathrm{~cm}, 240 \mathrm{~cm}$ の 3 点に, に拈いセ ンサー（新コスモス電機製，AET-S）を設置した。また， 温湿度計（ESPEC 製，RS-11）も同様に設置し，それ ぞれ調理 6 時間後まで測定した.

嗅覚測定に関しては, 調理開始前 (0 分), 調理終了直 後 (15 分), 調理終了 1 時間後 (1 時間 15 分), 調理終了 3 時間後 (3 時間 15 分), 調理終了 6 時間後（6時間 15 分）に採取した試料を用いて実施した。試料採取位置は 機器測定と同様の位置で $150 \mathrm{~cm}$ とした。試料採取は, 採取位置付近に待機した採取者が調理終了直後に発生源 方向を向き, $30 \mathrm{~L}$ の試料採取用袋（近江オドェアーサー ビス，フレックサンプラーF タイプ） と 15〜20 L/min のポンプ（近江オドェアーサービス，フレックスポンプ DC1-NA 型）を使用して行った. 試料採取の際には共洗 いを 1 回行った. 嗅覚測定では臭気濃度（三点比較式臭 袋法), 臭気質 (どんなにおいであるかを自由記述で回答 する方法）を测定した。
嗅覚測定は, T\&Tオルファクトメーター試薬を用い たパネル選定試験に合格した 6 名により行った. 嗅覚測 定の前には, 嗅覚測定法安全管理マニュアルに従い, 粘 膜刺激性等の観点から日本産業衛生学会よって示されて いる最大許容濃度や ACGIH (American Conference of Governmental Industrial Hygienists）による上限值ま たは 15 分間值で許容濃度が示されている有害物質には該 当していないことを確認した. また, パネルには, 実験に 使用する試料は一般の生活環境に存在するものであるこ と, 実験中も途中辞退が可能であること, 個人デー夕の特 定ができるような解析は行わないことを充分に説明し, 了解を得た後に筆者らの責任のもとで実験を行った.

\section{3. 結果}

\section{1 調湿建材の調理臭成分に対する吸着性能試験 (予備実験)}

表 -2 に調理直後に採取した臭気試料の臭気成分分析 結果を示す。分析した成分の中では閾值との関係からア セトアルデヒド, トリメチルアミンが感覚的に影響を及 ぼしていると考えられるが，臭気成分濃度としてはアン

\section{表 -2 焼肉調理直後の臭気成分分析結果}

\begin{tabular}{|c|c|c|c|}
\hline 物質名 & 濃度（ppb） & 検出下限值（ppb） & 閾值（ppb） \\
\hline 硫化水素 & $<0.9$ & 0.9 & 0.41 \\
\hline メチルメルカプタン & N.D. & 0.8 & 0.07 \\
\hline 硫化メチル & N.D. & 0.1 & 3 \\
\hline 二硫化メチル & N.D. & 0.2 & 2.2 \\
\hline アセトアルデヒド & 200 & 0.01 & 1.5 \\
\hline プロピオンアルデヒド & N.D. & 0.02 & 1 \\
\hline$n$-ブチルアルデヒド & N.D. & 0.02 & 0.67 \\
\hline イソブチルアルデヒド & N.D. & 0.02 & 0.35 \\
\hline n-バレルアルデヒド & N.D. & 0.01 & 0.41 \\
\hline イソバレルアルデヒド & N.D. & 0.01 & 0.1 \\
\hline プロピオン酸 & N.D. & 0.5 & 5.7 \\
\hline$n$-酪酸 & N.D. & 0.3 & 0.19 \\
\hline n-吉草酸 & N.D. & 0.2 & 0.6 \\
\hline イソ吉草酸 & N.D. & 0.2 & 0.078 \\
\hline イソブタノール & N.D. & 3 & 0.011 \\
\hline アンモニア & 794.36 & 50 & 1500 \\
\hline トリメチルアミン & 3.44 & 0.8 & 0.032 \\
\hline トルエン & 0.5 & 0.3 & 330 \\
\hline スチレン & 0.69 & 0.4 & 35 \\
\hline キシレン* & 0.29 & 0.2 & $* *$ \\
\hline
\end{tabular}

(注)*キシレンは $o$-キシレン, $m$-キシレン, $p$-キシレンをまとめたものである.

**閾值は 0 -キシレン : $380 \mathrm{ppb}, m$-キシレン $: 41 \mathrm{ppb}, p$-キシレン $: 58 \mathrm{ppb}$ である. 
モニアが最も高く, 測定が容易であることも考慮し, 予備 実験に使用する臭気成分としてアンモニアを選定した。

図-4に，試験体カラムのアンモニア吸着性能を示す。 アンモニアの出入口濃度が一致するまでに要した時間は 27 時間であった。図－5 に試験体カラムのアンモニア保

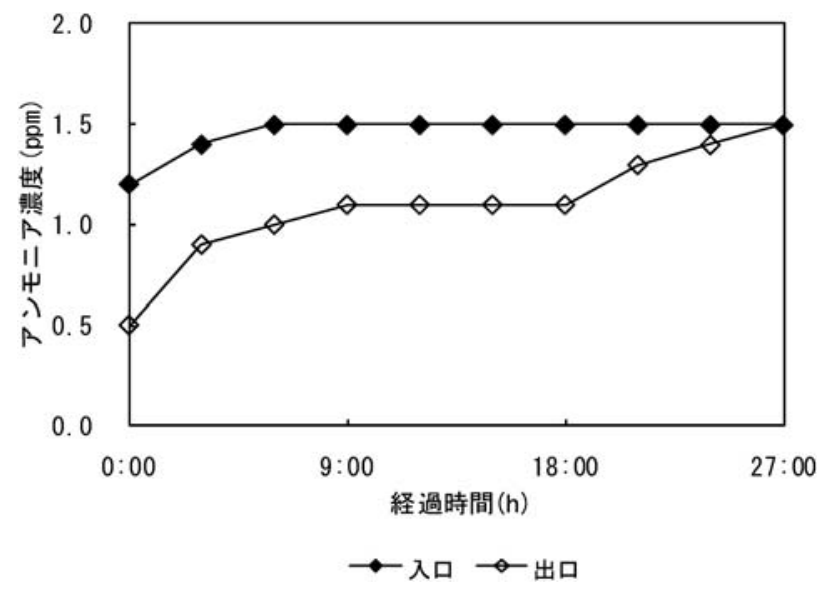

図-4＼cjkstart試験体カラムのアンモニア吸着性能

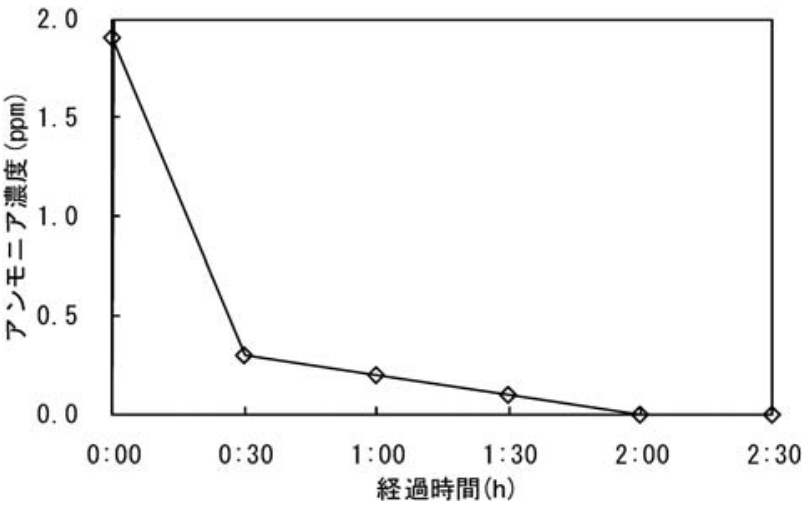

図－5＼cjkstart試験体カラムのアンモニア保持性能
持性能を確認するための再放出実験における出口のアン モニア濃度を示す。初期のアンモニア濃度は $1.9 \mathrm{ppm}$ で あったが，検出されるアンモニア濃度が徐々に低下して 行き，検出下限以下までに要した時間は 2 時間であっ た。この結果から，調理時に発生するアンモニアについ て，吸着の飽和を迎えると一部が再放出されるが，吸 着・保持性能を有することが認められた。

\section{2 調湿建材の調理臭に対する脱臭性能試験}

\section{2.1 調湿建材の調湿性能}

図-6に調理中および調理後の絶対湿度の増加量の変 化を示す。図には嗅覚測定の試料採取位置, 床上 $150 \mathrm{~cm}$ で測定した絶対湿度の増加量を示している．実験中の室 温の平均值は, レンジフードなしが $25^{\circ} \mathrm{C}$, 調湿 (天井)

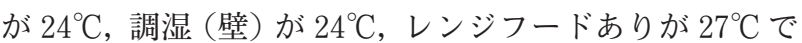
あり，調理前後の変化はいずれも $1^{\circ} \mathrm{C}$ 以内であった.

絶対湿度の変化量については, レンジフードありで は，ピーク時の増加量がレンジフードなしの約 $1 / 3$ であ り，レンジフードにより調理時の水蒸気が速やかに排出 されている，一方，調湿建材を設置した条件では，調湿 (天井) はピーク時の増加量がレンジフードなしの約 $1 / 2$ に抑えられており，調理により発生した水蒸気が天井面 へ上昇し，天井の調湿建材へ吸収された可能性が考えら れるが，調理終了 2 時間後から絶対湿度の減少がみられ なくなり, 調理時に発生し調湿建材に吸着した水蒸気が 再放出されている可能性が考えられる。調湿（壁）では， ピーク時の増加量はレンジフードなしとほとんど差がな いが，調理後からの絶対湿度の低下が速く，壁面へ設置 された調湿建材への吸着の影響と考えられる。以上よ り，調湿建材を設置した条件では，レンジフードありの 場合と比較すると調理時に発生した水蒸気の速やかな処

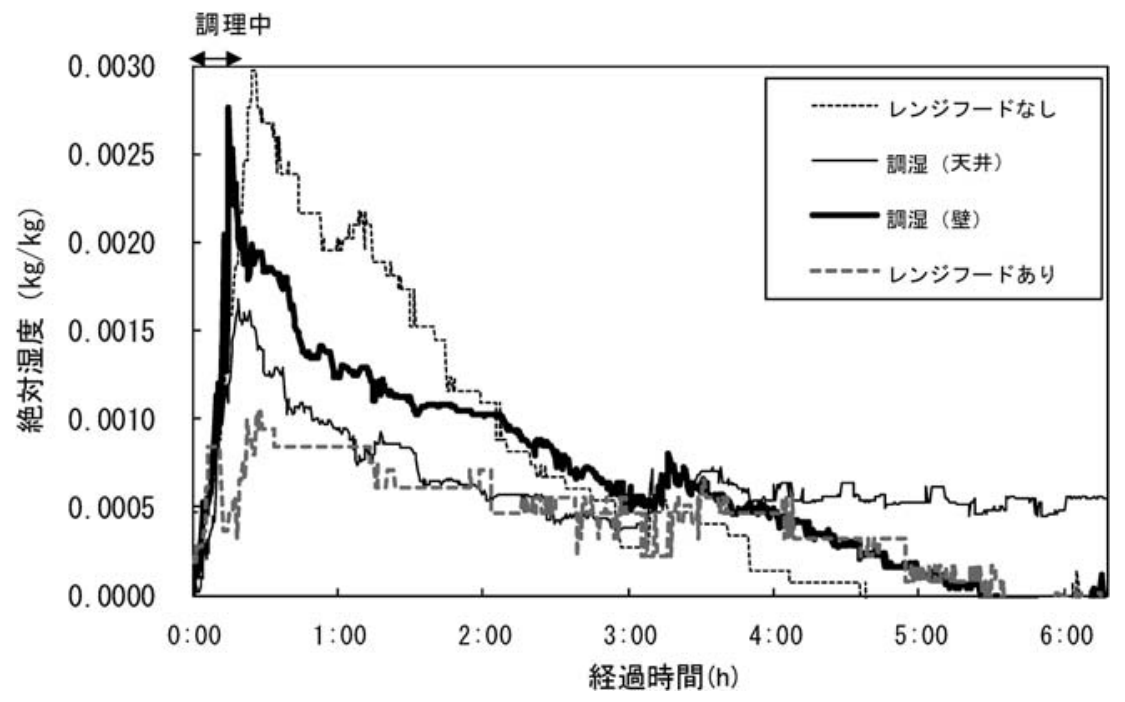

図－6 各条件における調理中および調理後の絶対湿度の増加量の変化 
理性能は劣るが，レンジフードなしの条件と比較して調 湿効果が認められた.

\subsection{2 調湿建材の脱臭性能}

（1）室内への臭気の残留状況

図ー7は，焼肉調理時の臭気指数とにおいセンサー值 の関係を示したものである. 本実験に使用したにおいセ ンサーが，焼肉の調理臭に関して感覚量と対応している ことを確認するため, 本研究の実験結果だけでなく，他 の目的で実施した本研究と同様のガラスの室内で実験し た焼肉調理のにおいに関する結果も用いて検討した ${ }^{10)}$. なお，すべて調理前の状態をにおいセンサー值 300 とし

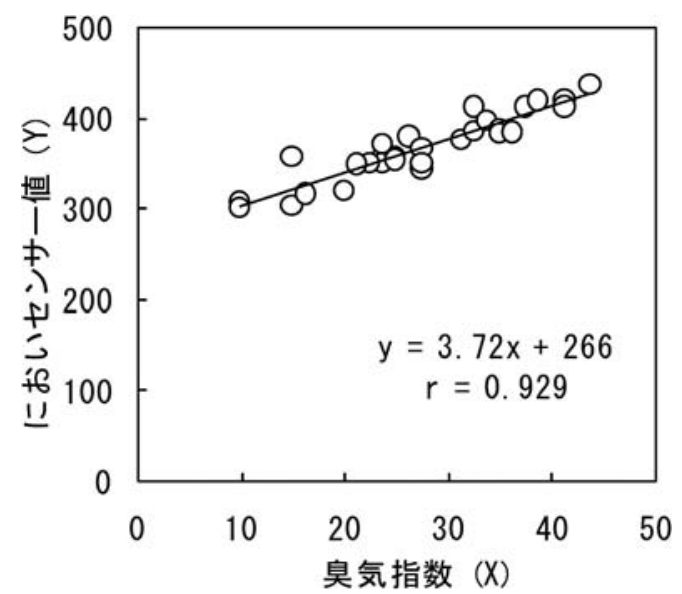

図 -7 焼肉調理時の臭気の臭気指数とにおいセンサー 値の関係

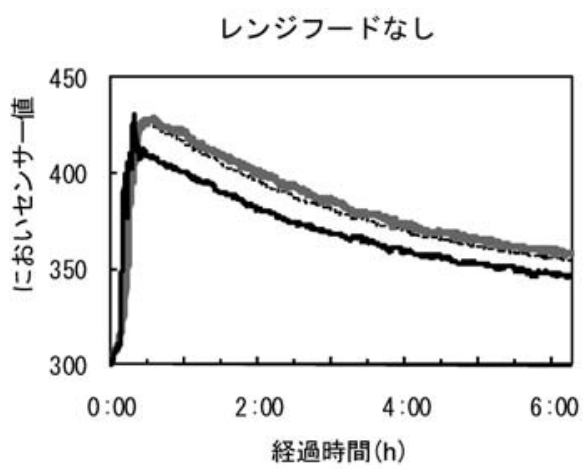

調湿（天井）

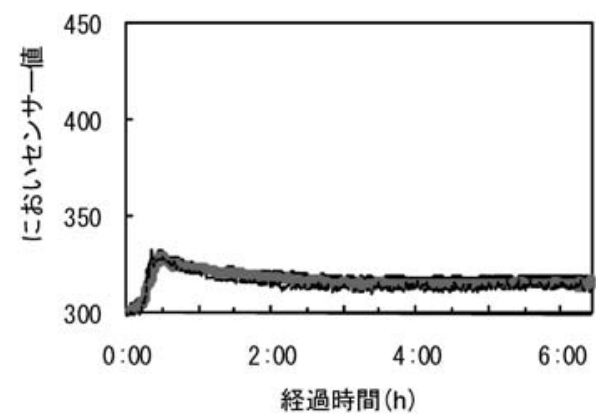

た，検討の結果，臭気指数とにおいセンサー值の相関係 数は 0.929 であり, 相関が認められた。

図-8に，各条件のにおいセンサー值の経時変化を示 す. 全体的に調湿（天井）の值が最も低く，調湿（壁） もレンジフードなしと比較して低い值を示しており，脱 臭効果が認められる，臭気の上下分布をみると，レンジ フードなしで $240 \mathrm{~cm}$ の值が若干低い以外は，ほぼ同様 の值の変動を示し, 上下分布は明確に認められなかっ た。図 -7 の臭気指数とにおいセンサー值の関係を参考 に，においセンサー值のピーク時の值を臭気指数に換算 すると，レンジフードなしでは臭気指数 44 (においセン サー值 431), 調湿 (天井) では臭気指数 18 (においセン サー值 333), 調湿（壁）では臭気指数 25（においセン サー值 360）となる。レンジフードありでは臭気指数 26 （においセンサー值 363）であることから, 調湿（天井） ではレンジフード以上の, 調湿 (壁) ではレンジフード と同等の効果が期待できる.

\section{(2) 臭気質の評価}

自由記述で回答された臭気質の内容を分類し，「焼肉 のタレのにおい」,「コンソメのにおい」などの回答を 「調味・香辛料系」としてまとめ, その回答率（回答数/ パネル数）を求めた。この評価では，においの強さに関 係なく，採取試料がどのようなにおいであったかを示し ている，床上 $150 \mathrm{~cm}$ の試料に対する調味・香辛料系の 回答率を図 -9 に示す。調湿建材を設置した条件では天

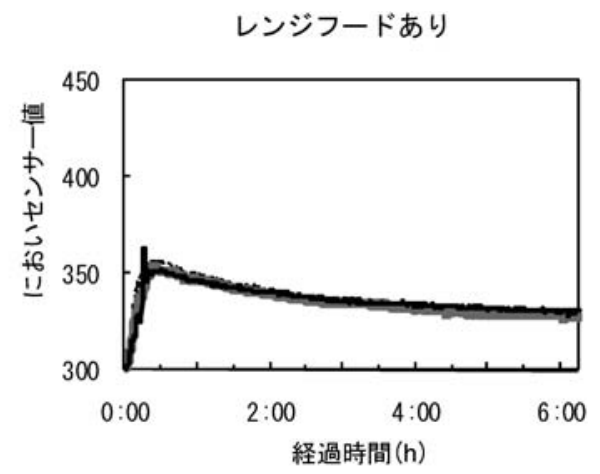

調湿(壁)

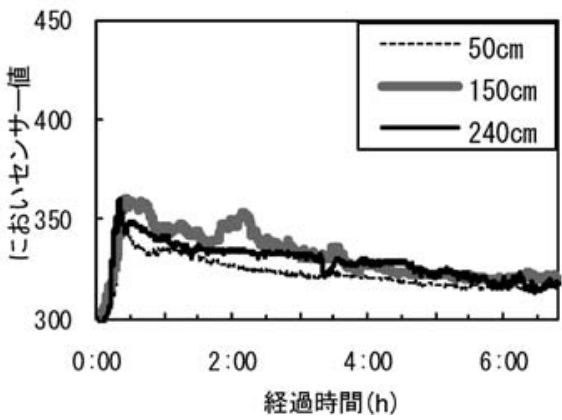

図－8 各条件における調理中および調理後のにおいセンサー值の経時変化 
井，壁ともに調味・香辛料系の回答率が急激に低下し， 調湿（壁）では調理終了 3 時間後に, 調湿（天井）では 調理終了 6 時間後に回答率は $0 \%$ になった。レンジフー ドあり, レンジフードなしでは調理終了 6 時間後でも調 味・香辛料系の回答率が約 $40 \%$ であった。レンジフー ドを調理中 15 分間運転しても全く運転しなかった時と 同様，調理終了 6 時間後に室内のにおいを調理による臭 気質と感じる場合があることが示唆された。調湿建材を 設置した条件では調理前と調理終了 3 時間後, 調理終了 6 時間後に「建材のにおい」「新築の家のにおい」の回答 率が 50\%〜 67\% を占めることから，室内へ設置した調 湿建材に関係する臭気質が感じられていると考えられ
る.レンジフードありおよびレンジフードなしの条件は 実験室の壁・天井はガラスであるが，調湿建材を設置し た条件では調湿建材と施工のために使用した材料があ り，ガラスにはない材料の臭気質が感じられたものと考 えられる。

（3） 臭気濃度の測定結果

図-10に，各試料の臭気濃度の測定結果を示す. 床上 $150 \mathrm{~cm}$ の值をみると, レンジフードなしの調理終了 3 時間後の值がレンジフードありの調理直後の值と同程度 であり，調理中にレンジフードを使用しない場合の臭気 対策の必要性が示めされている。

パネルの閾值（対数值）を基に，レンジフードなしと

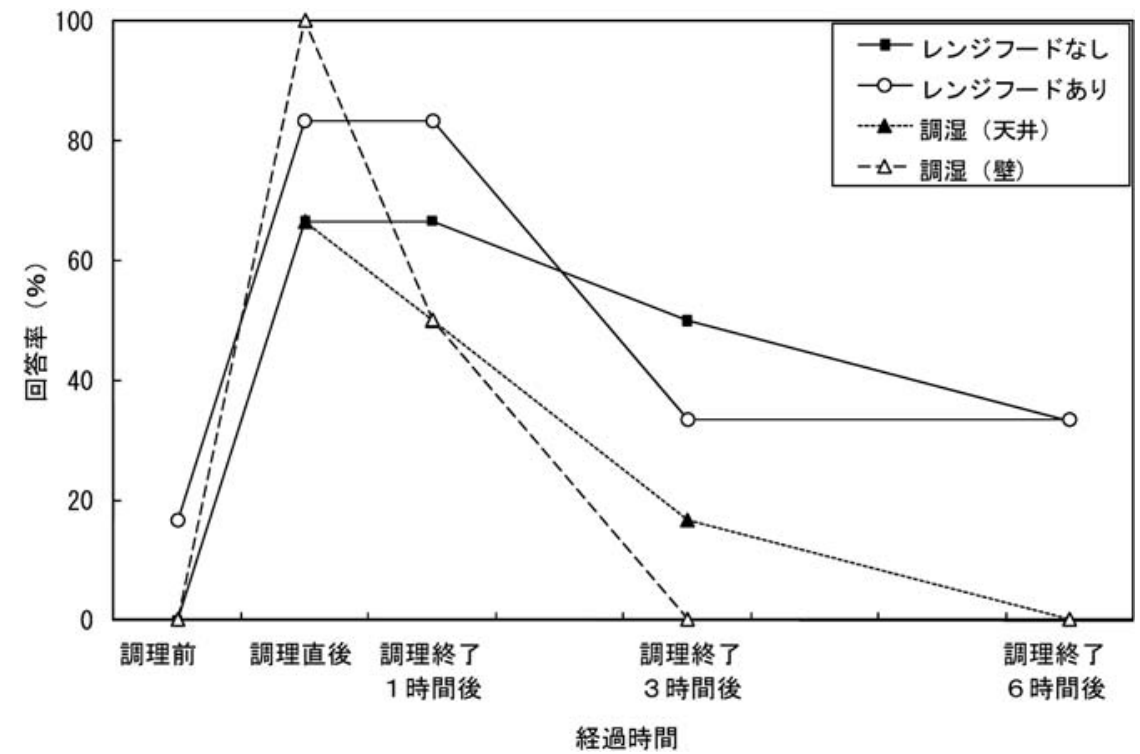

図－9 各条件の臭気試料に対する自由記述における調味・香辛料系のパネルの回答率

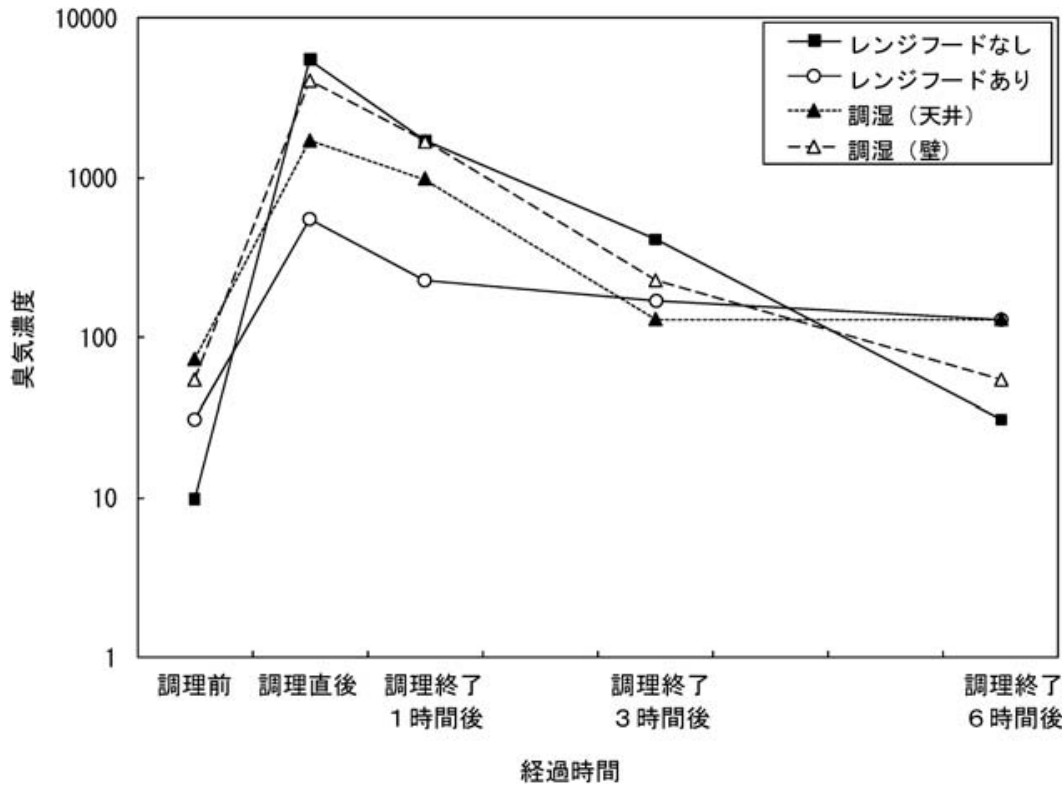

図ー10 各条件における床上 $150 \mathrm{~cm}$ で採取した臭気試料の臭気濃度の経時変化 
各条件の臭気濃度について差の検定 ( $\mathrm{T}$ 検定) を行った。 その結果, レンジフードなしと $5 \%$ 水準で有意差が認め られたのは, 調湿 (天井) では調理直後, 調理終了 3 時 間後であり, レンジフードありでは調理直後, 調理終了 1 時間後であった. 調湿 (壁)については有意差が認めら れなかった。

レンジフードなしの調理直後の臭気濃度に対する各条 件の臭気濃度の低減率を脱臭率とし, 各条件の調理直後 の脱臭性能の目安として用いた.レンジフードなしの臭 気濃度と有意差が認められた調湿 (天井), レンジフード ありの脱臭率を (式 1) より求めた. その結果, 調湿 (天 井) では 69\% (レンジフードなしの臭気濃度 5500 , 調湿 (天井) の臭気濃度 1700), レンジフードありではレンジ フードの捕集効率に近い值である $90 \%$ (レンジフードな しの臭気濃度 5500 , レンジフードありの臭気濃度 550) となった。

\section{脱臭率 $(\%)$}

$=\{($ レンジフードなしの調理直後の臭気濃度一各条 件の調理直後の臭気濃度)/レンジフードなしの調 理直後の臭気濃度 $\} \times 100$ (式 1)

臭気質評価から，調湿建材を設置した条件では建材の 設置に伴うにおいが臭気濃度へ影響している可能性が考 えられるため, 各条件において調理前の臭気濃度と調理 直後, 調理終了 1 時間後, 調理終了 3 時間後, 調理終了 6 時間後の臭気濃度の差の検定 ( $\mathrm{T}$ 検定) を行い, どの時 点で調理前の臭気濃度と有意差がみられなくなるかを検 討した，その結果，レンジフードなし，レンジフードあり では調理終了 6 時間後でも $5 \%$ 水準で有意差が認められ, 調理前の状態に戻っていないことが示された。一方, 調湿 （天井）では調理終了 3 時間後, 調湿 (壁) では調理終了 6 時間後に $5 \%$ 水準で有意差が認められなくなった。

以上より，レンジフードを調理時のみ運転し調理臭を 排出する現状の方法では, 調理中の臭気を速やかに排出 できるため調理直後の臭気濃度の低減には効果的である が, 室内へ臭気が残留した場合, 室内の 0.5 回/h 換気だ けでは調理終了 6 時間後も調理前の状態には戻らないこ とが明らかとなった。レンジフードを使用しない場合の 臭気対策を調湿建材で行う方法は, 脱臭効果が高い天井 へ設置した場合でも調理直後の脱臭率が $69 \%$ で, 調理 中 15 分間運転のレンジフードよりも劣る.しかし, 室内 へ残留した臭気の脱臭に有効であり, 調理前の臭気濃度 までに回復する時間は, 調理中 15 分間のレンジフード 運転条件よりも短くなることが明らかとなった。

\section{4. 結論}

LDK 空間における調理臭に対する調湿建材の脱臭性
能について，においセンサーによる臭気の残留状況，臭 気質評価, 臭気濃度の測定結果を総合的に考えると, 調 理中 15 分間運転のレンジフードには劣るが, 室内へ残 留した臭気の脱臭には効果的である。 また, 調理臭対策 として調湿建材を設置する場合には, 壁面よりも天井面 へ設置した方が効果の高いことが示された.

本研究では, 調理時および調理終了 6 時間後までの脱 臭性能を検討したが, 予備実験として行ったアンモニア の吸着性能試験で示されたとおり, 臭気物質の吸着の飽 和が起こると一部が再放出される可能性があるため, 今 後は調湿建材の脱臭性能の持続性の検討が必要である.

\section{謝辞}

本実験にご協力下さいました被験者の皆様, ならびに オペレーターとしてご協力下さいました当時の卒論生高 木誠一路氏, 高木優氏, 根本富志生氏に厚く御礼申し上 げます。なお, 本研究の一部は財団法人トステム建材産 業振興財団の助成を受け行ったものである.

キーワード : 調理臭, 調湿建材, 臭気濃度, においセン サー, 脱臭性能

\section{参考文献}

1 ）五十嵐由利子, 中村和吉, 永井廉子, 石津京二, 古賀 修, 宮永俊之, 占部 亘, 阪本郁代, 中島明子: 電磁調理器 使用時の臭気拡散と臭気評価に関する研究, 人間 - 生活環 境系シンポジウム報告集，37-40，（2004）

2 ) 小川晴久, 中村 誠, 福田弥生, 柴原数雄, 西垣康広, 伊 藤国億, 成瀬哲哉, 藤巻吾朗, 松井永子, 折居建治, 近藤直 実 : 調湿建材の使用が室内環境及び人体に与える影響調査 に関する研究, 室内環境, 125-131，(2009）

3 ) 黒田健一, 光田 恵, 吉野 博, 池田耕一: 高歯者施設の 居室における臭気特性と対策に関する研究, 第 16 回にお い・かおり環境学会講演要旨集，50-51，(2003）

4) 鈴木昭人, 川合秀治, 田辺新一: 多孔質セラミックス調 湿建材に関する研究 (小型チャンバーADPACを用いたホ ルムアルデヒド吸着性能評価), 日本建築学会学術講演梗 概集 D-2，995-996，（2002）

5 ）桑沢保夫, 大澤元毅, 岡部 実: 実大実験室による吸着 性建材の効果確認実験, 日本建築学会学術講演梗概集 D-2, 981-982, (2006)

6 ) 横田知博, 加藤信介, 村上周三, 安宅勇二, 徐 長厚 : 室 内空気污染濃度低減材の濃度低減性能に関する研究, 日本 建築学会環境系論文集，No. 620，37-42，（2007）

7 ) 小峯裕己, 木村 洋, 中邨 隆, 喜多純一: におい識別装 置を用いた消臭建材の性能試験, 日本建築学会学術講演梗 概集 D-2，867-868，（2008）

8 ) 吉田和之, 磯本淳貴, 今井秀秋, 光田 恵, 柏原誠一, 松 田克己: 焼肉臭気成分の同定と市販内装材の臭気低減効果 の検討, におい・かおり環境学会誌, 39 巻 2 号, 126-134, (2008) 
9 ) 悪臭法令研究会：(2001) ハンドブック悪臭防止法，ぎょ うせい

10）光田 恵, 中村太樹, 姉川哲也, 小林和幸 : 室内に扔ける
調理臭の拡散・残留特性に関する研究，日本建築学会大会 学術講演梗概集，999-1000，（2005）

\title{
Research on the Deodorization Efficiency of Indoor Cooking Odors by the Humidity Control Materials
}

\author{
Toshimi TANAMURA*, Megumi MITSUDA**, Hiroatsu SASAKI***, \\ Kazuyuki KOBAYASHI ${ }^{* * * *}$ \\ * Graduate School of Engineering, Daido University, \\ 40, Hakusui-cho, Minami-ku, Nagoya-shi, Aichi, Japan \\ ** Odor and Aroma Design, Department of Information Design,School of Informatics, \\ Daido University, 10-3, Takiharu-cho, Minami-ku, Nagoya-shi, Aichi, Japan \\ *** Formerly, Graduate School of Engineering, Daido University, \\ 40, Hakusui-cho, Minami-ku, Nagoya-shi, Aichi, Japan \\ **** R \& D Center, Tokyo Electric Power Company, \\ 4-1, Egasaki-cho, Tsurumi-ku, Yokohama-shi, Kanagawa, Japan
}

\begin{abstract}
We focused on the humidity control material as a means to control indoor cooking odors For the purpose of understanding the deodorization efficiency of the building material, we measured the removal effect of ammonia by the small sample. And we measured cooking odors of the room $(3640 \mathrm{~mm} \times 7280 \mathrm{~mm} \times 2500 \mathrm{~mm})$ where the humidity control material was used on the ceiling or the wall for 6 hours. The measurement items were odor concentration, odor quality, odor sensor vale, room temperature and humidity.

The odor concentration and odor sensor value in the room with the humidity control material on the ceiling were low compared with the value of the room with the humidity control material on the wall. The deodorization efficiency was demanded by the reduction rate of odor concentration of cooking end in the room with the humidity control material on the ceiling for the condition without the range hood, and the value was $69 \%$. The humidity control material was quite effective for the removal of remained odor in the room.
\end{abstract}

Key words : cooking odor, humidity control materials, odor concentration, odor sensor, deodorization efficiency 